\title{
POSSIBILITIES OF IMPROVING PILOT'S SITUATIONAL AWARENESS THROUGH THE SHAPING OF THE HUMAN-MACHINE INTERFACE IN MILITARY AIRCRAFT COCKPITS
}

\author{
MOŻLIWOŚCI POPRAWY ŚWIADOMOŚCI \\ SYTUACYJNEJ PILOTA POPRZEZ KSZTALTOWANIE \\ INTERFEJSU CZLOWIEK-MASZYNA W KOKPITACH \\ WOJSKOWYCH STATKÓW POWIETRZNYCH
}

\author{
Waldemar Gołębiowski ${ }^{1}$ Leszek Loroch $^{2}$ \\ (1) Wyższa Szkoła Oficerska Sił Powietrznych \\ Polish Air Force Academy \\ 08-530 Dęblin, ul. Dywizjonu 303 nr 12 \\ (2) Instytut Techniczny Wojsk Lotniczych \\ Air Force Institute of Technology \\ 01-494 Warsaw, ul. Księcia Bolesława 6
}

e-mails: (1) pigeon7@wp.pl, (2) leszek.loroch@itwl.pl

\begin{abstract}
With determined individual perception capability, the pilot's safety during a flight depends on his situational awareness formed by information from the surrounding environment. The graphical data information may be modeled and performed to the pilot by a data interface of research simulator. The method of testing human-machine interface (HMI)described in this paper enables detecting special incidents (critical situations) influencing flight safety, and help making prevention efforts. The proposed research method can result in developing solutions for shaping the data interface, as well as ergonomic solutions in cockpits of military aircraft.
\end{abstract}

Keywords: situational awareness, research simulator, aviation safety, perception

Streszczenie: Przy określonej, indywidualnej zdolności percepcyjnej, bezpieczeństwo pilota w czasie lotu zależy od jego świadomości sytuacyjnej kształtowanej przez informację pozyskaną $\mathrm{z}$ otaczającego środowiska. Informacja w postaci graficznej może być zamodelowana i przekazana pilotowi przez pole informacyjne symulatora badawczego. Opisana w artykule metoda badań interfejsu człowiek-maszyna z wykorzystaniem symulatora badawczego pozwala wykryć przypadki szczególne (sytuacje krytyczne) wpływające na bezpieczeństwo lotów oraz opracować przedsięwzięcia zapobiegające ich powstawaniu. Zaproponowana metoda badawcza umożliwić może opracowanie propozycji w zakresie kształtowania pola informacyjnego oraz rozwiązań ergonomicznych w kokpitach wojskowych statków powietrznych.

Słowa kluczowe: świadomość sytuacyjna, symulator badawczy, bezpieczeństwo lotów, percepcja, pole informacyjne 


\section{POSSIBILITIES OF IMPROVING PILOT'S SITUATIONAL AWARENESS THROUGH THE SHAPING OF THE HUMAN-MACHINE INTERFACE IN MILITARY AIRCRAFT COCKPITS}

\section{Introduction}

Situational awareness (SA) appeared in the considerations of aviation researchers at the end of 1980s as an element of aviation training. Then, SA was perceived as appropriate for the current flight status/stage perception of the surroundings, understanding the importance of the elements perceived, and predicting the possibilities of their status changing in the near future [6]. Unlike the traditional human-machine interface (HMI) models, the aviation HMI model allows for no operation automation and predicting progress of the situation more than reacting to the situation. Thus, research ought to allow for understanding the situation and transforming it into appropriate decisions, not only perception and reactions. SA-related problems are particularly severe in general aviation (GA), where $85 \%-90 \%$ of accidents are related to an inexperienced pilot taking a wrong decision resulting from SA-related problems. Similarly, problems may occur in the aviation rescue services [10], where even experienced pilots with significant flying time may find themselves in such meteorological and area conditions that, in order to improve SA, technical (IT) support enabling maintenance of the required task realisation safety level is necessary. To detect, model and enable improvement with respect to critical situations (SA), a research approach (simulator) of the HMI was suggested.

Modern, optimised and integrated IT may improve situational awareness, but the improvement may only be useful when the operator (pilot) takes advantage of the possibility of taking a better decision more promptly. The aim while designing the HMI is to achieve a 'decision-related advantage', not only 'IT advantage' as such. In situations in which range, speed, performance and cost of weapons increase, human cognitive process (perception) must be accelerated by the 'automated' situation assessment and the ability to act accordingly (decision). Such an approach constitutes a new challenge to researchers in experimental and development programmes, especially in military operating systems. 


\section{Elaboration}

The role of situational awareness in the decision-making process in a highly dynamic environment, that being the flight, has been shown in fig. 1 developed by M. Endsley [6].

The figure shows the possibility of taking a decision depending on the level of situational awareness, allowing for other factors.

The first level of information (level 1) in achieving situational awareness is the pilot's discerning variable elements in the dynamic environment. For the pilot, it is necessary to have such information as: aeroplane technical condition, speed, location, altitude, course, as well as the weather, communication with the air traffic control, etc.

At the second level (level 2), understanding the situation is based on the synthesis of the elements from level 1. From separate pieces of information, the pilot has to work out the course of action/changes enabling transition from a specific state (level 1) to the expected state. A pilot with insignificant experience may successfully achieve level 1 , but also may not be able to integrate numerous variables, dynamic elements within time required to take a decision.

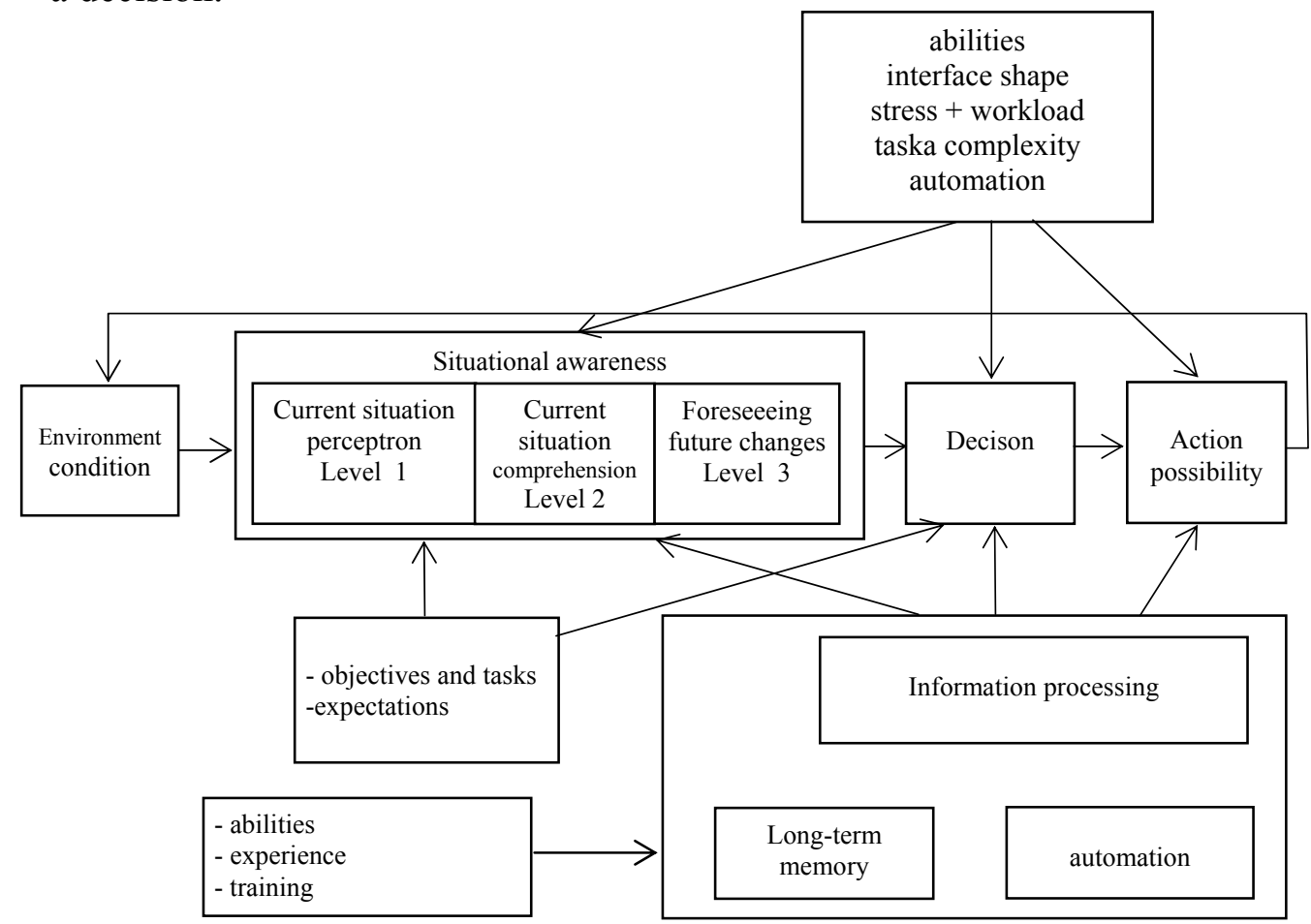

Fig. 1. Model of situational awareness during pilot decision-making (M. Endsley 1995b) 
At the third level (level 3), ability to predict the progress of the situation minimum in the nearest future is required. This ability is particularly important in the event of predicting weather changes and how a change of course would affect collision situations. Obvious is the fact that in specific atmospheric conditions the pilot may pay more attention (perception) to other elements of developing situations awareness.

Analysing the presented model of situational awareness, it may be expected that requirements regarding situational awareness depend not only on the pilot/operator's predispositions, the surrounding environment, and the ability to act, but also on the human-aeroplane interface shape, pilot workload, onboard equipment automation/integration level and, in particular, the information processing process applied. In recent years, particularly important has become the fusion of data allowing for providing the pilot with information integrated from more than one sensor, which reduces the workload greatly, shortens the information utilisation process and, in most critical cases during the flight, enables transition to level 2 in the situational awareness model. An example of such a solution may be presentation of a tactical situation on one of the displays in the aircraft cabin.

Implementation of digital technology instead of analogue technology on the aircraft board implies the possibility of providing great volumes of information to the human-machine interface displays. Still, excess of information may create a critical situation and the pilot/operator's transition from level 1 to further levels $(2,3)$, and taking a decision will take too long even in the case of a pilot having skills, experience and appropriate level of training. An attempt to investigate into the problem was made in the research and development project no. 0002/R/z/T00/06/02.

Station presented in fig. 1 enables not only optimisation of the humanmachine interface, but also allows for the assessment of its operation in critical situations. Detection of critical situations and optimisation of the pilot's actions in these situations may enable correct shaping of the information area in military aircraft cockpits as well as development of standards regarding information which may be provided to the pilot. 


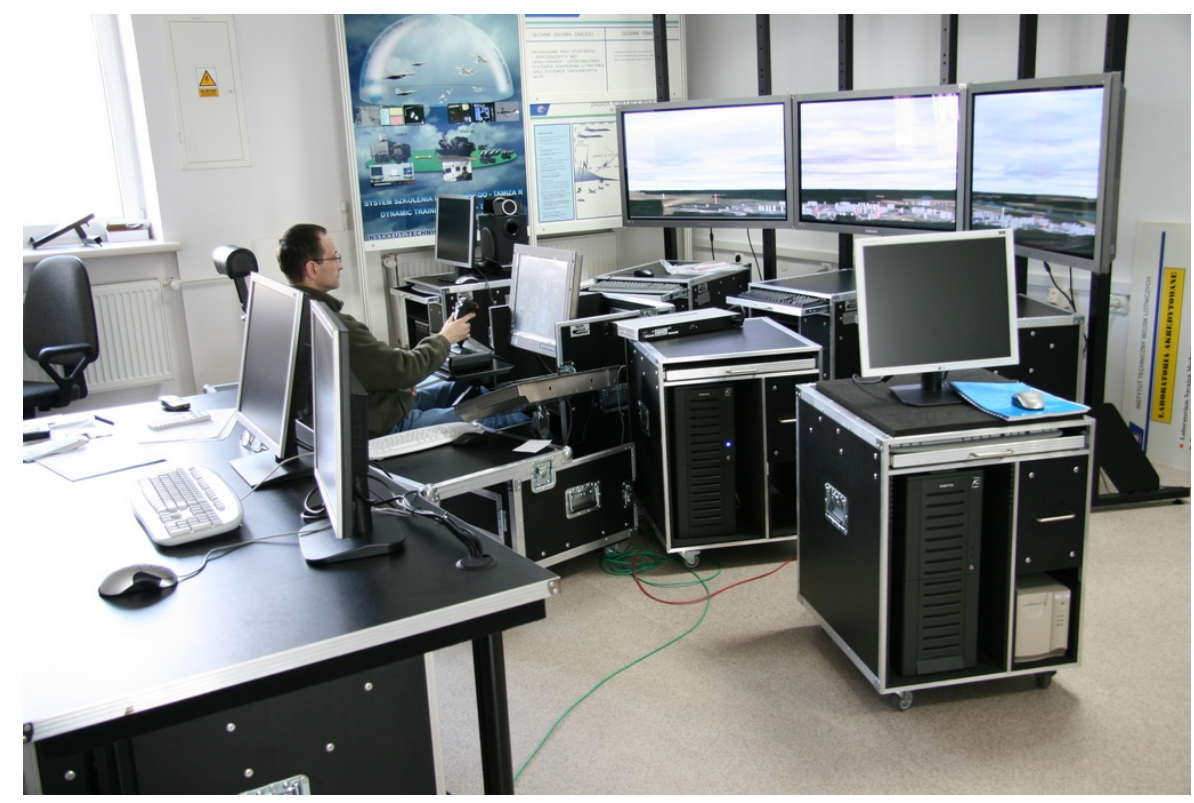

Fig. 1. Research and construction simulator. General view

Representation of an aircraft cockpit or an unmanned aircraft ground post should be qualitatively similar to the actual; sources of the information provided to the pilot/operator should be represented, and the possibility of entering visual and audio interferences should be ensured [2].

Assessing the pilot/operator's psychomotor efficiency at the research station, reaction time was selected a method to assess the human operator's action reliability [4]. Reaction time comprises two basic variables: time required to take a decision on the action and time of the very action. Due to the need to receive information from the entire field of vision, registration of eye movement as attention indicator has been implemented. Additionally, the post will make it possible to measure the pulse as an indicator of cognitive load, and to determine the intellectual fatigue based on the aggravation of action realisation caused by long-time performance of them. Intellectual fatigue may be determined with the critical flicker fusion frequency (CFFF) method and the subjective assessment on the NASA TLX scale. Allowing for the aforementioned measurement-related requirements and the need to generate the surrounding environment, fig. 2 suggests a block diagram of the research and construction simulator. 


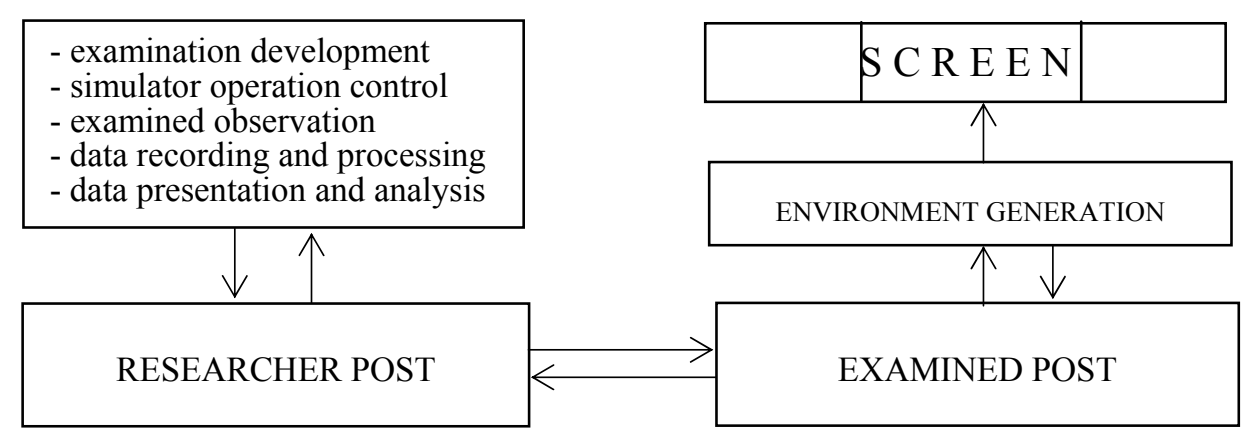

Fig. 2. Research and construction simulator block diagram

\section{Improvement of the pilot/operator's situational awareness vs. task realisation safety}

In many cases, the need to improve situational awareness leads to partial replacement of the aviation electronics in the aircraft cabin, which is often related to the repair and modernisation of the whole avionics. An example of such an approach are battle helicopters: AH-64 Apache, MH 47 Chinook, UH/MH-60 Black Hawk, W-3WA Sokól and others. Implementation of the Multifunction display (MFD) into the cabin and of a computer on the board makes the aviation electronics become hybrid avionics as the remaining part of the cabin equipment remains there. The problem is solved in another way in the newly-designed aircrafts, where analogue instruments are being eliminated and the whole creates the so-called 'glass cockpit'.

In the case of a hybrid cockpit, the aircraft crew are required to be able to operate both analogue and digital instruments. The problem has been investigated into in passenger civil aviation and provided positive results, but in the case of helicopters, the nature of the flight is absolutely different and involves the need to conduct additional studies. Comparative studies conducted at the Aviation Research Laboratory in Fort Rucker (14) showed that the rate of accidents for the 'glass cockpit' was higher than for the traditionally equipped cockpit. In the accident involving $\mathrm{OH}$ 58D helicopters it appeared that the helicopter was charged with additional tasks to an extent resulting in the loss of situational awareness in critical situations. A similar situation occurred in the case of the AH-64D Apache, where the workload is significantly higher than in the AH-64A version. So, it appeared that the workload, safety, situational awareness and training are, in pilots' opinions, a derivative of the designed pilot's work post - the cockpit. On the other hand, conducted studies showed in this situation that it is necessary to intensify the training and to upgrade the training programmes so that the level of pilots' abilities ensures the required level of safety. 
In the case of the 'glass cockpit' full version with the possibility of utilising battlefield digital simulation, research is conducted in real time (real time man-in-the-loop helicopter mission simulator). Such an approach enables detailed testing of all the mission elements, leading to a satisfactory level of situational awareness at all the mission levels with the use of the data fusion then presented on the tactical situation displays. Obvious is the fact the equipment version featuring comprehensive fusion of onboard data and data provided by means of external links is present in the combat version, with the occurrence of real battlefield threats. For training purposes, sufficient is the basic version utilising onboard sensors and a digital map.

In the future cockpits of military aircraft, comprehensive (integrated) avionic solutions corresponding with operating scenarios and combat tasks realised by the $\mathrm{AC}$ crews should be expected. The number of system control manual elements must be limited mainly because of safety reasons as well as aviation training costs. Alternative methods of control onboard of an AC may be methods related to voice recognition and pilot/operator's head movement tracking.

\section{Summary}

1. Works on the possibility of improving the pilot's situational awareness through the shaping of the human-machine interface are being extensively conducted by all aviation electronics manufacturers, especially including manufacturers of military aircraft avionics.

2. Making use of the information advantage, coming both from onboard sensors and external systems may ensure effective task realisation at the battlefield while ensuring a high level of crew safety.

3. Technical aspects of the improvement of situational awareness onboard of an aircraft primarily depend on the human-machine interface shape, the possibility of processing the information onboard of the aircraft, of the onboard sensors acquiring the information and provision of it via links from external tactical systems.

4. Information presented in the aircraft cockpit must ensure understanding of the current situation, allow for predicting changes, taking a decision, and then action adequate to the process.

5. The research station developed allows for the optimisation of the humanmachine interface, with particular attention paid to critical situations. In the development version, the research post should enable testing the software implemented onboard of military aircraft. 


\section{Bibliography}

1. Dołęga B., Gruszecki J., Kopecki G., Pieniążek J., Rogalski T., Rzuciło P., Tomczyk A. ”Opracowanie technologii oraz stanowiska do optymalizacji interfejsu czlowiek-maszyna wkokpicie wojskowych statków powietrznych”. Politechnika Rzeszowska, 2007.

2. Endsley M. R. (1995b) "Toward the theory of situation awareness" Human Factors, 37 (1), 32-64

3. Hesselink H. H., Zon G. D. R (Rolf), Tempelman F.(Frank), Beetstra J. W. (Jelle), Vollebregt A. M. (Arjen), Hannessen D. P. (Dann). National Aerospace Laboratory, NLR, Amsterdam. 'On Board Decision Support through the Integration of Advanced Information Processing and Human Factors Techniques'. The Power Project.

4. Marsh Howard S., Quinn Paul W., Toth Gary J., LCDR Jakubek David A. Office of Naval Research, Arlington Tactical Decision Making: 'The Interaction of Human Perception and Judgment with Automated Information Processing and Presentation'. II. Decision Support

5. Mejdal Sig, McCanley Michael E., Beringer Dennis B. Human Factors Design Guidelines for Multifunction Displays Find Report. Office of Aerospace Medicine, Washington, DC U.S. Department of Transportation, FAA. 2001.

6. Rash Clarence E., Adam Gina E., LeDuc Patricia A., Francis Gregory "Pilot Attitudes on Glass and Traditional Cockpits in the U.S. Army's AH-64 Apache helicopter". Presented at the American Helicopter Society 59 $9^{\text {th }}$ Annual Forum, Phoenix, AZ, May 6-8 2003.

7. Rash C. E., Suggs C. L., LeDuc P. A., Adam G. E., Manning S. D., Francis G., and Nobak R. "Accident Rates in Glass Cockpit Model U.S. Army Rotary Wing Aircraft". Fort Rucker, AL.: US Army Aeromedical Research Laboratory. USA ARL Report No 2001-12. 2001

8. Shook Richard W. C. "Situation awareness problem is general aviation" Proceedings of $14^{\text {th }}$ Triennial Congress of the International Ergonomics Association and $44^{\text {th }}$ Annual Meeting of the Human Factors and Ergonomics Society - 2000.

9. Skibniewski F. Truszczyński O. Tarnowski A. Różański K. "Opracowanie technologii oraz stanowiska optymalizacji interfejsu człowiek-maszyna...”. Sprawozdanie z pracy. Warsaw, 2007.

10. Szczepański C. et al. "Opracowanie technologii oraz stanowiska do optymalizacji interfejsu człowiek-maszyna $w$ kokpicie wojskowych statków powietrznych”. Projekt wstępny. Warsaw, 2007. 
11. Verhoeven R. P. M. de Reus A. J. C. "Prototyping Interactive Cockpit Application". National Aerospace Laboratory NLR, NLR-TP-2005066.

12. Vollebregt A. M., Hannessen D. P., Hesselink H. H., Beetstra J. W. Modelling Crew Assistants with multi-agent systems in fighter aircraft. National Aerospace Laboratory NLR, NLR-TP-2002-347 


\section{MOŻLIWOŚCI POPRAWY ŚWIADOMOŚCI SYTUACYJNEJ PILOTA POPRZEZ KSZTALTOWANIE INTERFEJSU CZLOWIEK-MASZYNA W KOKPITACH WOJSKOWYCH STATKÓW POWIETRZNYCH}

\section{Wstęp}

Świadomość sytuacyjna pojawiła się w rozważaniach badaczy lotniczych pod koniec lat osiemdziesiatych XX w. jako element szkolenia lotniczego. Postrzegano wtedy SA jako odpowiednią dla bieżącego stanu/etapu lotu percepcję otoczenia, rozumienie znaczenia postrzeganych elementów oraz przewidywanie możliwości zmiany ich stanu w najbliższym czasie [6].

Od modeli tradycyjnych interfejsu człowiek-maszyna lotniczy model HMI uwzględnia brak automatyzacji działania oraz uwzględniania przewidywania rozwoju sytuacji bardziej niż reagowanie na sytuację. Dlatego w badaniach uwzględnić należy rozumienie sytuacji i przetworzenie jej na odpowiednie decyzje, a nie tylko postrzeganie i reakcje. Problemy w zakresie SA występują szczególnie ostro w lotnictwie ogólnym, gdzie 85\%-90\% wypadków związanych jest z podjęciem przez niedoświadczonego pilota błędnej decyzji wynikającej z problemów SA. Podobne problemy występować mogą w służbach ratownictwa lotniczego [10], gdzie nawet doświadczeni piloci z dużym nalotem mogą znaleźć się w takich warunkach meteorologicznych i terenowych, że dla poprawy SA niezbędne jest wsparcie techniczne (informatyczne) umożliwiające zachowanie niezbędnego poziomu bezpieczeństwa wykonania zadania. Do wykrycia, modelowania oraz umożliwienia poprawy w zakresie sytuacji krytycznych (SA) zaproponowano stanowisko badawcze (symulator) interfejsu człowiek-maszyna (HMI).

Nowoczesna, zoptymalizowana i zintegrowana technologia informatyczna może poprawić świadomość sytuacyjną, ale poprawa ta może być użyteczna tylko wtedy, jeśli operator (pilot) wykorzysta tę możliwość do szybszego podjęcia lepszej decyzji. Celem działania podczas projektowania interfejsu człowiek-maszyna HMI jest osiagnięcie ,przewagi decyzyjnej”, a nie tylko „przewagi informatycznej” jako takiej. W sytuacji, kiedy zasięg, prędkość, efektywność i koszt broni rośnie, ludzki proces poznawczy (percepcja) musi zostać przyspieszony przez „zautomatyzowaną” ocenę sytuacji oraz zdolność podjęcia prawidłowego działania (decyzji). Takie podejście stanowi nowe wyzwanie dla badaczy w programach eksperymentalnych i rozwojowych, szczególnie w wojskowych systemach operacyjnych. 


\section{Rozwinięcie}

Rolę świadomości sytuacyjnej $\mathrm{w}$ procesie podejmowania decyzji w środowisku o dużej dynamice jakim jest lot przedstawiono na rys. 1 opracowanym przez M. Endsley [6]. Na rysunku przedstawiono możliwość podjęcia decyzji $\mathrm{w}$ zależności od poziomu świadomości sytuacyjnej przy uwzględnieniu pozostałych czynników.

Pierwszym poziomem informacji $\mathrm{w}$ osiągnięciu świadomości sytuacyjnej jest dostrzeżenie przez pilota elementów zmiennych w dynamicznym środowisku. Dla pilota niezbędne jest posiadanie informacji takich jak: stan techniczny samolotu, prędkość, położenie wysokość, kurs, a także stan pogody, łączność ze stanowiskiem kierowania ruchem lotniczym itp.

$\mathrm{Na}$ drugim poziomie zrozumienie sytuacji bazuje na syntezie elementów $\mathrm{z}$ poziomu 1. Pilot musi $\mathrm{z}$ oddzielnych danych wypracować kierunek działania/zmian umożliwiający przejście $\mathrm{z}$ określonego stanu do stanu oczekiwanego. Pilot $\mathrm{z}$ niedużym doświadczeniem może $\mathrm{z}$ powodzeniem osiagnąć poziom 1, ale może nie być $\mathrm{w}$ stanie zintegrować wielu zmiennych, dynamicznych elementów w czasie niezbędnym do podjęcia decyzji.

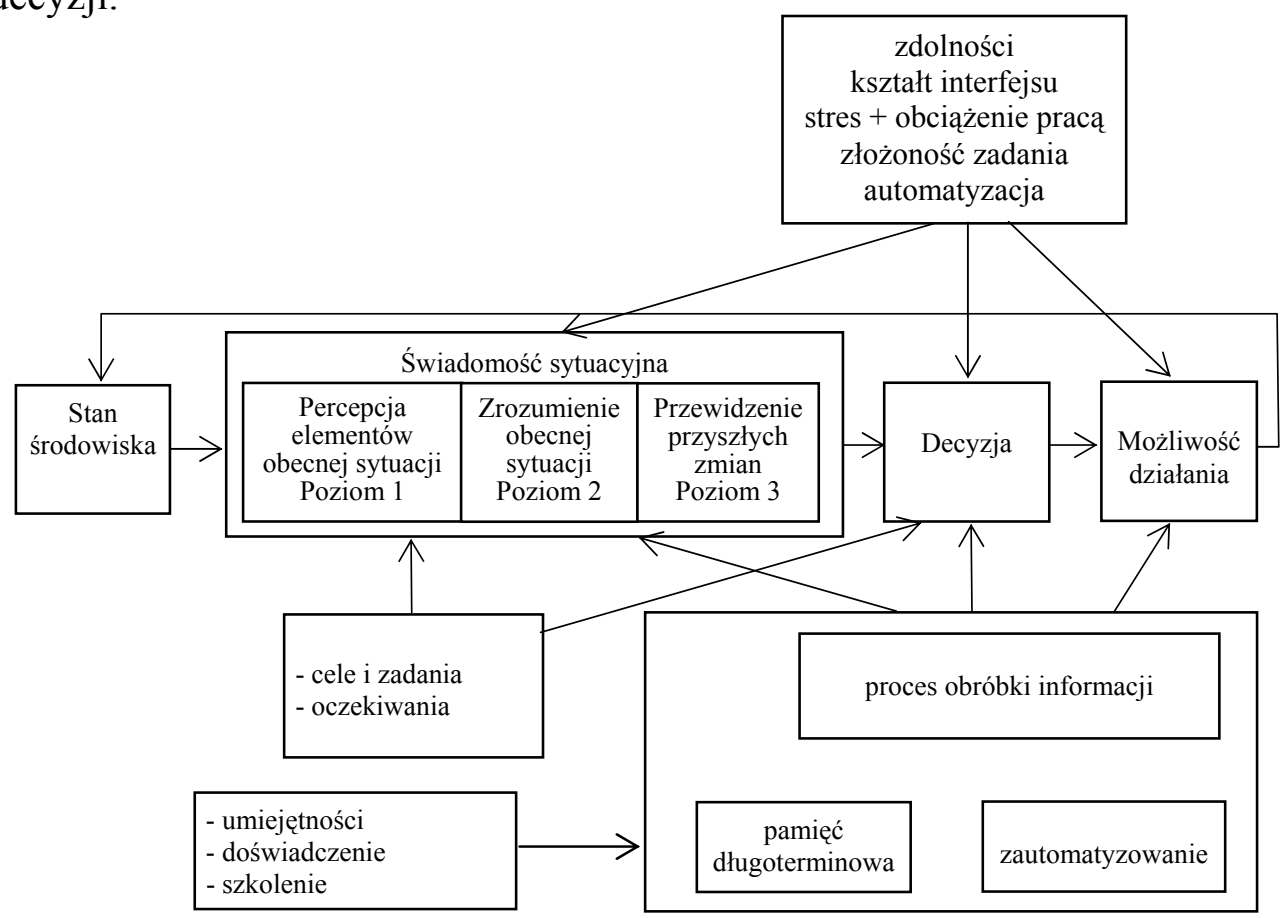

Rys. 1. Model świadomości sytuacyjnej podczas podejmowania decyzji przez pilota (M. Endsley 1995b) 
$\mathrm{Na}$ poziomie trzecim niezbędna jest zdolność do przewidzenia rozwoju sytuacji przynajmniej w najbliższym czasie. Zdolność ta jest szczególnie istotna $\mathrm{w}$ przypadku przewidywania zmian pogody oraz jak zmiana trasy lotu wpływać może na sytuacje kolizyjne. Oczywistym faktem jest, że $\mathrm{w}$ ustalonych warunkach atmosferycznych pilot więcej uwagi (percepcji) może poświecić innym elementom budowania świadomości sytuacyjnej.

Analizując przedstawiony model świadomości sytuacyjnej można oczekiwać, że wymagania dotyczące świadomości sytuacyjnej są zależne nie tylko od predyspozycji pilota/operatora, stanu otaczającego środowiska, możliwości działania, ale i od kształtu interfejsu pilot-samolot, obciążenia praca pilota, poziomu automatyzacji/integracji wyposażenia pokładowego, a w szczególności zastosowanego procesu obróbki informacji. W ostatnim okresie szczególnego znaczenia nabiera fuzja danych umożliwiająca podanie pilotowi zintegrowanej informacji $\mathrm{z}$ więcej niż jednego sensora co znakomicie zmniejsza obciążenie praca, skraca proces wykorzystania informacji i pozwala w znacznej części przypadków krytycznych w locie przechodzić do poziomu $2 \mathrm{w}$ modelu świadomości sytuacyjnej. Przykładem takiego rozwiązania może być przedstawienie sytuacji taktycznej na jednym z monitorów w kabinie statku powietrznego.

Wprowadzenie techniki cyfrowej w miejsce techniki analogowej na pokłady statków powietrznych implikuje możliwość wyprowadzenia na monitory interfejsu człowiek-maszyna ogromnej ilości informacji. Jednak nadmiar informacji może stworzyć sytuację krytyczną i przejście pilota/operatora z poziomu 1 do dalszych poziomów $(2,3)$ oraz podjęcia decyzji przebiegać będzie zbyt długo nawet $\mathrm{w}$ przypadku pilota posiadającego umiejętności, doświadczenie i z odpowiednim poziomem wyszkolenia. Próbę przebadania tego problemu podjęto $\mathrm{W}$ projekcie badawczo-rozwojowym nr 0002/R/z/T00/06/02.

Przedstawione na zdj. 1 stanowisko umożliwia nie tylko optymalizację interfejsu człowiek-maszyna, ale również umożliwia ocenę działania tego interfejsu w sytuacjach krytycznych. Wykrycie sytuacji krytycznych i optymalizacja działań pilota $\mathrm{w}$ tych sytuacjach umożliwić może właściwe ukształtowanie pola informacyjnego w kokpitach wojskowych statków powietrznych, a także opracowanie standardów w zakresie zasobu informacji możliwej do przekazania pilotowi. 


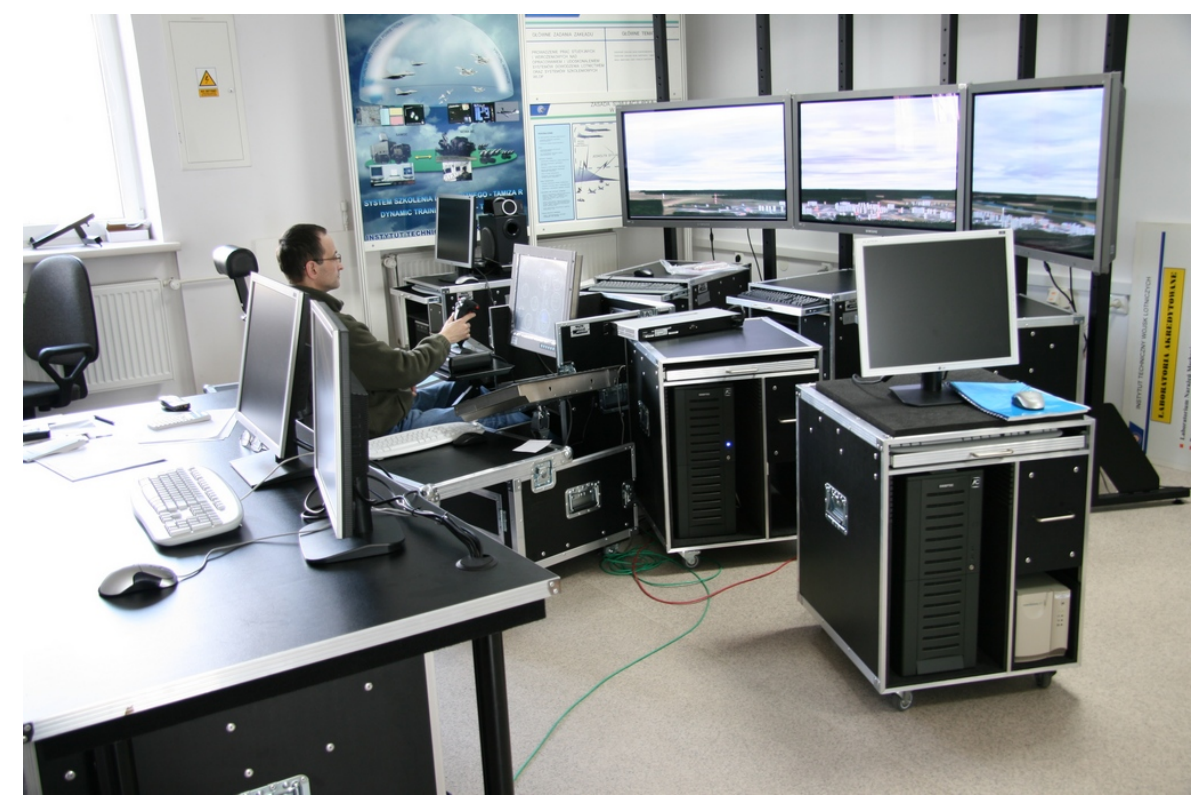

Zdjęcie 1. Symulator badawczo-konstrukcyjny. Widok ogólny.

Odwzorowanie kokpitu statku powietrznego lub stanowiska naziemnego pilota bezpilotowego statku powietrznego (BSP) powinno być jakościowo podobne do rzeczywistego, odwzorowane powinny być źródła przekazywanej pilotowi/operatorowi informacji oraz powinna być zapewniona możliwość wprowadzania zakłóceń wzrokowych i dźwiękowych [2].

Oceniając sprawność psychomotoryczną pilota/operatora na stanowisku badawczym wybrano czas reakcji jako metodę oceny niezawodności działania człowieka operatora [4]. Na czas reakcji składają się dwie podstawowe zmienne: czas potrzebny do podjęcia decyzji o działaniu oraz czas samego działania. $Z$ uwagi na konieczność odbioru informacji z całego obszaru pola widzenia wprowadzono rejestrację ruchów oka jako wskaźnik uwagi. Dodatkowo na stanowisku możliwe będzie mierzenie tętna jako wskaźnika obciążenia poznawczego oraz określenie zmęczenia umysłowego na podstawie pogorszenia realizacji czynności spowodowanych długotrwałym ich wykonywaniem. Zmęczenie umysłowe określane może być metodą krytycznej częstotliwości migotania (CFFF - critical flicker fusion freguency) oraz ocenę subiektywną na skali NASA - TLX. Uwzględniając powyższe potrzeby pomiarowe i konieczność generacji otaczającego środowiska zaproponowano na rys. 2 schemat blokowy symulatora badawczo-konstrukcyjnego 


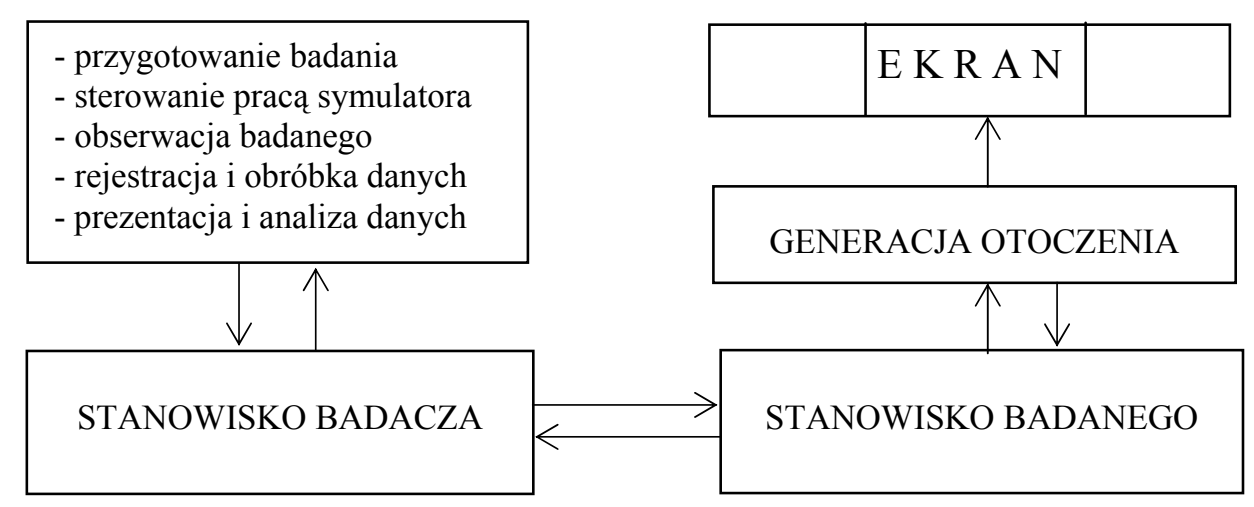

Rys. 2. Schemat blokowy symulatora badawczo-konstrukcyjnego

\section{Poprawa świadomości sytuacyjnej pilota/operatora, a bezpieczeństwo wykonywania zadań}

W wielu przypadkach konieczność poprawy świadomości sytuacyjnej prowadzi do cześsiowej wymiany awioniki w kabinie statków powietrznych, co często połączone jest z remontem i modernizacją całości. Przykładem takiego podejścia są śmigłowce bojowe: AH-64 Apache, MH- 47 Chinook, UH/MH-60 Black Hawk, W-3WA Sokół i inne. Wprowadzenie do kabiny MFD (Multifunction Display), a na pokład komputera powoduje, że awionika staje się hybrydową, ponieważ pozostała część wyposażenia kabiny pozostaje. Inaczej problem jest rozwiązywany w nowoprojektowanych statkach powietrznych, gdzie eliminuje się przyrządy analogowe, a całość tworzy tzw. ,glass cockpit”.

W przypadku kokpitu hybrydowego od załogi statku powietrznego wymagana jest umiejętność posługiwania się zarówno przyrządami analogowymi jak i cyfrowymi. Problem ten przebadany został $\mathrm{w}$ pasażerskim lotnictwie cywilnym $\mathrm{z}$ wynikiem pozytywnym, ale $\mathrm{w}$ przypadku śmigłowców charakter lotu jest zupełnie inny i powoduje konieczność prowadzenia badań dodatkowych. Badania porównawcze przeprowadzone w Lotniczym Laboratorium Badawczym w Fort Rucker (14) pokazały, że wskaźnik wypadków dla kokpitu w wersji „glass cockpit” był wyższy niż dla kokpitu $\mathrm{z}$ wyposażeniem tradycyjnym. W wypadku śmigłowców OH-58D okazało się, że śmigłowiec został w takim stopniu obciążony dodatkowymi zadaniami, że doprowadziło to do utraty świadomości sytuacyjnej w sytuacjach krytycznych. Podobna sytuacja wystąpiła w przypadku śmigłowca AH-64D Apache, gdzie obciążenie praca jest znacznie wyższe niż na wersji AH-64A. Tak więc okazało się, że 
obciążenie praca, bezpieczeństwo, świadomość sytuacyjna i szkolenie są, zdaniem pilotów, pochodną zaprojektowanego stanowiska pracy pilota kokpitu. Przeprowadzone z kolei badania wykazały w takiej sytuacji, że niezbędne jest zintensyfikowanie szkolenia i uaktualnienie programów szkolenia tak, aby poziom umiejętności pilotów zapewnił wymagany poziom bezpieczeństwa.

W przypadku pełnej wersji „glass cockpit” z możliwością wykorzystania symulacji cyfrowej pola walki prowadzi się badania na symulatorach misji w czasie rzeczywistym. Podejście takie umożliwia szczegółowe testowanie wszystkich elementów misji, doprowadzenie do zadowalającego poziomu świadomości sytuacyjnej na wszystkich etapach misji $\mathrm{z}$ pełnym wykorzystaniem fuzji danych przestawionych następnie na monitorze sytuacji taktycznej. Oczywistym faktem jest, że wersja wyposażenia z pełną fuzją danych pokładowych i dostarczonych danych przy pomocy łączy z zewnątrz występuje w wersji bojowej, przy występowaniu zagrożeń realnego pola walki. Dla celów szkoleniowych wystarczająca jest wersja podstawowa $\mathrm{z}$ wykorzystaniem sensorów pokładowych oraz mapy cyfrowej.

W przyszłościowych kokpitach wojskowych statków powietrznych oczekiwać należy kompleksowych (zintegrowanych) rozwiązań awionicznych odpowiadających scenariuszom operacyjnym oraz zadaniom bojowym wykonywanym przez załogi SP. Ilość elementów kontroli manualnej systemu musi być ograniczona głównie ze względów bezpieczeństwa, a także kosztów szkolenia lotniczego. Alternatywnymi metodami kontroli na pokładzie SP mogą być metody związane $\mathrm{z}$ rozpoznawaniem głosu oraz śledzeniem ruchów głowy pilota/operatora.

\section{Podsumowanie}

1. Prace nad możliwością poprawy świadomości sytuacyjnej pilota przez kształtowanie interfejsu człowiek-maszyna są intensywnie prowadzone przez wszystkich producentów awioniki statków powietrznych, w tym szczególnie producentów awioniki wojskowych statków powietrznych.

2. Wykorzystanie przewagi informacyjnej, pochodzącej zarówno z sensorów pokładowych, jak i systemów zewnętrznych zapewnić może efektywne wykonanie zadań na polu walki przy zapewnieniu wysokiego poziomu bezpieczeństwa załogi.

3. Techniczne aspekty poprawy świadomości sytuacyjnej na pokładzie statku powietrznego uzależnione są głównie od kształtu interfejsu człowiek-maszyna, możliwości obróbki informacji na pokładzie statku 
powietrznego, pozyskania tej informacji przez sensory pokładowe oraz dostarczone łączami z taktycznych systemów zewnętrznych.

4. Przedstawiona w kokpicie statku powietrznego informacja musi zapewnić zrozumienie bieżącej sytuacji, umożliwić przewidzenie zmian, podjęcie decyzji, a następnie adekwatne do tego procesu działanie.

5. Opracowane stanowisko badawcze umożliwia optymalizacje interfejsu człowiek-maszyna ze szczególnym uwzględnieniem sytuacji krytycznych. W wersji rozwojowej stanowisko badawcze umożliwić powinno testowanie oprogramowania implementowanego na pokładach wojskowych statków powietrznych.

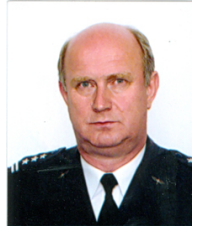

Ph.D., Eng., LOROCH Leszek, AFIT, R\&D coordinator of aeronautical projects. Specialist in the field of aircraft armament. Experienced in designing, testing, and implementation of modernized on-board aircraft armament and air combat assets. Former member of the commission for aircraft accidents investigation. A lot of publications in the field.

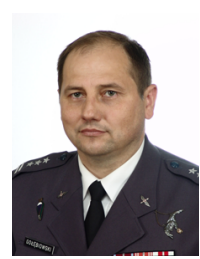

Col. Pilot Waldemar Gołebiowski, MSc Eng., heads the Training Division at Wyższa Szkoła Oficerska Sił Powietrznych (Polish Air Force Academy) in Dęblin. Master rated pilot. Certified flight instructor and experimental test pilot. Areas of scientific interests: training systems for different aircraft types, aeronautical equipment/air armament testing, aircraft reliability and safety. Participant of international exercises to train air forces of NATO member countries. 